\title{
El poder de la verdad: política y religión en el pensamiento político del siglo XVII
}

\author{
Luis Ignacio Iriarte \\ Universidad Nacional de Mar del Plata / CONICET \\ iriarteignacio@yahoo.com.ar
}

Recepción: 17/03/2014, Aceptación: 30/06/2014, Publicación: 17/12/2014

\section{Resumen}

En este trabajo propongo una interpretación de las obras de Pedro Ribadeneyra, Baltasar Alamos de Barrientos, Pedro Barbosa Homen, Diego Saavedra Fajardo, Baltasar Gracian y José Alfonso Lancina. En la primera parte sostengo que Ribadeneyra y Álamos establecen los dos polos entre los cuales se mueve el pensamiento político español. Ambos defienden el sistema monárquico y entienden que la política está subordinada espiritualmente a la religión, pero se diferencian porque el primero propone una rearticulación ortodoxa de la política a la moral y las obligaciones religiosas, mientras que el segundo asume de manera clara el realismo político y le confiere una plena autonomía a la razón de Estado. En la segunda y la tercera parte aspiro a demostrar que Barbosa, Saavedra y Gracián toman como punto de partida una perspectiva cercana a la de Ribadeneyra, pero le confieren una progresiva autonomía a la política y establecen una secularización gradual del pensamiento sobre el Estado. En esa línea, Lancina finalmente separa la política de la moral, aunque sin abandonar la subordinación espiritual a Dios. En la última parte establezco una serie de reflexiones sobre las indagaciones de los autores en relación con los problemas jurisdiccionales entre el Estado y la Iglesia. A partir de esta última cuestión, concluyo que el pensamiento político español es una forma de reflexionar y sostener intelectualmente la monarquía de los Habsburgo.

Palabras clave

Barroco; política; moral; religión

\footnotetext{
Abstract

The power of truth: politics and religion in the political thought of the seventeenth century In this paper, I propose an interpretation of the works of Pedro Ribadeneyra, Baltasar
} 
Alamos de Barrientos, Pedro Barbosa Homen, Diego Saavedra Fajardo, Baltasar Gracian and José Alfonso Lancina. In the first part I argue that Ribadeneyra and Alamos are the two poles between which the Spanish political thought moves. Both defend the monarchical system and understand that politics is spiritually subordinated to religion. However, they differ because Ribadeneyra proposes an orthodox re-articulation of politics to moral and religious obligations, while Álamos clearly assumes political realism and gives full autonomy to the reason of state. In the second and the third part I intend to demonstrate that Barbosa, Saavedra and Gracian take as their starting point ideas similar to that of $\mathrm{Ri}$ badeneyra, but they propose a progressive autonomy and secularization of politics. In that vein, Lancina finally separates politics from morality, but without abandoning the spiritual subordination to God. In the last part, I analyze the opinions of the authors on the links between the State and the Church. Based on this question, I conclude that the Spanish political thought is a way to reflect and strengthen the Habsburg monarchy.

Keywords

Baroque; politics; morals; religion

Los siglos XVI y XVII conforman un período fundamental para el pensamiento político y son una cantera en la que se diseñan tanto las ideas sobre el Estado que estuvieron vigentes durante la Edad Moderna como así también muchas de las condiciones bajo las cuales entendemos todavía hoy algunas de las características del poder gubernamental. El epicentro de esta "revolución» se encuentra en las ciudades italianas durante las primeras décadas del 1500. En El Príncipe, Nicolás Maquiavelo fractura la visión tradicional de la política como una rama de la moral al recomendar al gobernante que utilice la mentira y la crueldad como mecanismos indispensables para conservar el Estado, y le aconseja que finja poseer las virtudes morales sin rendirse a sus principios, colocándose por encima de la religión. Aunque el florentino fue ampliamente criticado, esta fractura de la política respecto de la moral y la religión constituye, en parte, un descubrimiento de lo que comenzaba a vislumbrarse como el verdadero ejercicio del poder. Por esta razón, la obra de Maquiavelo impregna el pensamiento político de los siglos XVI y XVII aun en aquellos escritores que rechazaron explícitamente sus ideas, pues todos debieron rendirse a la evidencia de que los gobernantes requerían al menos cierta cuota de realismo y una capacidad para evaluar las circunstancias a la hora de actuar. 
Para Frank Ankersmit, la influencia de Maquiavelo puede comprenderse a partir de dos variantes que, aunque en muchos casos se superponen, permiten delimitar los polos entre los que se mueve el pensamiento político durante el Barroco: los arcana imperii y la razón de Estado. La primera de estas variantes tiene como principales figuras a Gabriel Naudé y Louis Machon y busca poner de relieve que el príncipe debe actuar de modo diferente al de los particulares, porque muchas veces está obligado a tomar decisiones que atentan contra la moral como mecanismo para conservar el Estado (como dice Maquiavelo, «uno principe, e massime uno principe nuovo, non può osservare tutte quelle cose per le quali gli uomini sono tenuti buoni, sendo spesso necessitato, per mantenere lo stato, operare contro alla fede, contro alla carità, contro alla umanità contro alla religione» (1995: 118 $)^{1}$ ). La segunda de estas variantes propone que la acción se encauce por caminos aceptables e intenta rearticular la política con la moral y la religión. Si bien esta perspectiva es una consecuencia de Maquiavelo, hay que agregar que en general los autores que la conforman definieron la razón de Estado a partir de críticas explícitas al autor de El príncipe $e^{2}$. En Della ragion di stato (1589), libro fundamental para este campo de reflexión, Giovanni Botero ataca de manera vehemente la idea de que la política se opone a la ley de Dios e intenta demostrar que el príncipe debe gobernar por medio de acciones virtuosas.

En Espańa, el pensamiento político tiene su momento de inflexión con la traducción de la obra de Botero por parte de Antonio Herrera en 1593. Aunque hay algunos autores que en principio son difíciles de clasificar, en general los españoles asumieron parte del realismo político que puso en evidencia Maquiavelo y buscaron definir una razón de Estado que conjugara ese realismo con los principios morales y religiosos. En parte debido a este carácter mixto, las interpretaciones clásicas discrepan en cuanto al sentido que se les debe dar a los numerosos tratados españoles. Para José Antonio Maravall hay que comprenderlos como consecuencia de la interdicción de las obras de Maquiavelo por parte de Roma en 1554³. Continuando en este sentido la obra de Gabrielle Toffani Maquiavelo e il tacitismo, el historiador sostiene que los españoles buscaron por otros caminos las ideas del florentino y recurrieron especialmente a los Anales de Cornelio Tácito: «Los puros comentaristas de Tácito, un poco como los puros comentadores de Aristóteles

1. En Naudé, el ejemplo característico es el golpe de Estado, que si bien es un medio inmoral, podría servir en determinadas circunstancias para conseguir el bienestar de la sociedad. Como demuestra Peter Donaldson, para Naudé la acción del príncipe es una imitatio dei, pues con los arcana imperii éste se sitúa en las paradojas y las complejidades de las relaciones entre el bien y el mal (1992: 174). La obra de referencia es, evidentemente, Considérations politiques sur les corps d'etat. 2. Para Michel Foucault, la razón de Estado es una superación de Maquiavelo, pues éste produjo una serie de recomendaciones para que el príncipe conservara su dominio, pero no un arte de gobernar, que sería lo propio de la razón de Estado (2006: 284-285). La hipótesis de que la razón de Estado es una crítica a Maquiavelo está propuesta por Michell Senellart (1989) y Elena Cantarino (1998).

3. En España la censura de la obra de Maquiavelo se demoró hasta 1583. 
en filosofía, se reducen a una razón sin el auxilio de la fe y resultan, como consecuencia de este proceder, francamente maquiavelistas» (1975: 81). Aunque resulta convincente para entender a autores como Baltasar Álamos de Barrientos y José Alfonso Lancina, esta interpretación tiene sus límites porque no permite explicar otros aportes, como los que hicieron los jesuitas en sus influyentes tratados sobre política. José Antonio Fernández-Santamaría superó ese escollo en Razón de Estado y política en el pensamiento español del Barroco. Según el autor, los tratados políticos le prestaron una atención creciente a la autonomía del Estado, pero entendieron que esa autonomía estaba subordinada a la religión.

Aunque tiene ya varios años, la tesis de Fernández-Santamaría es cautivante porque aspira a describir autores ortodoxos como Ribadeneyra y autores que en cambio reivindicaron una visión autónoma de la política. El pensamiento político español sería de manera unitaria un intento de responder a la crisis entre política y religión que Maquiavelo puso en evidencia a principios del siglo XvI. Pero al recorrer el libro se tiene la impresión de que la multiplicidad de autores estudiados se impone sobre la buscada unidad. Fernández-Santamaría fragmenta su objeto en tres escuelas: la eticista, la idealista y la realista. Aunque debemos comprenderlas como categorías abstractas creadas por el investigador a fin de ordenar el objeto de estudio, esta decisión termina por escindir la historia de la razón de Estado. Por este motivo, se llega a la inevitable conclusión de que el pensamiento español se mueve por dos ramales bien diferenciados: una primera visión que busca subordinar la política a la religión y una segunda que reclama una completa autonomía.

En este trabajo me propongo volver a la tesis de Fernández-Santamaría y demostrar que en España el pensamiento político es efectivamente unitario y que los autores que lo componen constituyen las aristas de un núcleo ideológico compartido. Para esto, creo que es necesario destacar una serie de puntos centrales. Ante todo, que existe una diferencia importante entre el descubrimiento de Maquiavelo y la solución que éste le da al problema, porque una cosa es la comprobación de que la política tiene reglas propias y otra muy distinta es la conclusión de que el príncipe puede y debe colocarse por encima de la moral y la religión. En sintonía con esto, está claro que los españoles descubrieron el realismo político en Maquiavelo, pero les bastaba con levantar la vista y contemplar la práctica real de los Habsburgo para tomar conciencia de que éstos actuaban muchas veces según la conveniencia y la utilidad a fin de mantener el Estado. La unidad del pensamiento español se encuentra, justamente, en que los autores piensan y defienden ese sistema de poder, basado en un complejo entramado de poder político y eclesiástico. Por esta razón, todos entienden que la política está subordinada a lo religioso, pero se distinguen a partir del modo en que conciben esa dependencia, tanto en términos cuantitativos (¿qué grado de autonomía se le puede conceder a un príncipe?) como así también en términos cualitativos, pues la subordinación a lo religioso quiere decir cosas distintas si la pensamos como una cuestión espiritual o si la pensamos también como una cuestión jurisdiccio- 
nal ${ }^{4}$. Como aspiro a demostrar en la última parte de este trabajo, esto permite decir que el pensamiento político español es una reflexión sobre el sistema de poder de los Austrias. El vínculo estrecho con ese sistema, que tras la paz de Westfalia se encuentra en franco retroceso, les permite a los tratadistas mostrar algunas de las condiciones bajo las cuales se levanta el poder gubernamental a lo largo de nuestra modernidad. A diferencia de Maquiavelo, el pensamiento español sostiene que, para ser efectivo y duradero, el poder y la verdad deben estar íntimamente vinculados y, para lograr esa articulación, los autores entienden que la política tiene que nutrirse de una fuente de legitimidad como la religión. Los siglos pasaron y la fuente de legitimidad se reemplazó por la nación, pero los pensadores del Barroco descubrieron que, por más realista e hipócrita que puedan ser algunas acciones puntuales, el gobierno se sostiene gracias a que acepta el dominio de algo que todos creemos que está por encima de nuestras voluntades y nuestras vidas.

\section{Los dos polos de la razón de Estado}

El pensamiento político puede comprenderse a partir de dos autores que se oponen de manera clara y que establecen, por lo tanto, un campo para establecer caminos intermedios: Pedro de Ribadeneyra y Baltasar Álamos de Barrientos. El primero fija su posición en Tratado del príncipe cristiano (1595). En esa obra, Ribadeneyra rechaza a Maquiavelo y se propone demostrar que la política, la moral y la religión constituyen un todo indisociable que permite poner en pie un gobierno duradero. Para el autor, el monarca debe mostrarse obediente a los principios católicos no solo porque está obligado a hacerlo, sino también porque orientan líneas de acción que son de una gran utilidad. El príncipe debe distribuir los bienes y los castigos de una manera equitativa y según los merecimientos, pues de ese modo no solo se gana el cielo, sino que también logra mantener el consenso de la monarquía. Pero sobre la base de esta visión tradicional, Ribadeneyra hace algunas concesiones a la práctica concreta del poder. El punto central de su propuesta se encuentra en el muy comentado pasaje en el cual se refiere a la mentira. Para Ribadeneyra, el príncipe nunca debe mentir, porque su palabra tiene que «ser como una palabra de Dios, verdadera, cierta, constante y segura» (287-288), pero muchas veces está obligado a ocultar lo que piensa, porque suele tratar con personas en las que, por regla general, no puede confiar ${ }^{5}$. Con esto, rechaza la simulación, que entiende

4. Sobre la importancia de las jurisdicciones en el pensamiento político de los jesuitas, ver José Francisco Aranda Pérez y David Martín López (2012).

5. «Y para poner fin a esta materia de la simulación del Príncipe, digo que así como de la víbora se compone la triaca, que es medicina contra la ponzońa de la misma víbora, pero para que aproveche es menester que sea poca la cantidad, y que vaya corregida y preparada con otros medicamentos saludables; así de esta simulación y ficción artificiosa se debe usar solamente cuando lo pide la necesidad; y que sea poca la cantidad, y con su dosis y tasa, y confeccionada con las leyes de la Cristiandad y prudencia; porque así se aprovechará y tendrá fuerza contra los Príncipes hipócritas, que como víbo- 
como sinónimo de la mentira, y, en dosis controladas, acepta la disimulación, es decir, el silencio del soberano. Por este camino, Ribadeneyra se sitúa en un pensamiento político tradicional: pone en primer plano la religión y restaura la continuidad entre política, moral y catolicismo, pero acepta cierto realismo y le confiere una autonomía relativa al Estado ${ }^{6}$.

Dos décadas más tarde, Álamos de Barrientos toma una dirección opuesta. En Tácito español (1614), intenta demostrar que la política constituye una ciencia que tiene reglas propias. Esta ciencia se apoya en dos ámbitos de conocimiento: por una parte, en las almas de las personas, las familias, las profesiones y las naciones sobre las que el príncipe ha de reinar y, por la otra, en la historia. Como observa en la dedicatoria y la advertencia de su obra, y como señala Antonio de Covarrubias en la aprobación, la historia es una cantera en la cual se encuentran los efectos que producen las más diversas acciones y, por lo tanto, permite elaborar una serie de máximas que orienten al príncipe a fin de decidir en cada ocasión en particular ${ }^{7}$. Por esta vía, que Álamos pone en práctica al traducir a Tácito y escribir innumerables aforismos en sus márgenes, propone que la política es autónoma y que los gobernantes tienen que guiarse casi exclusivamente por la utilidad. Según sostiene en la dedicatoria al duque de Lerma, son tres «los cabos por donde se ha de hacer juicio en los discursos de estado, para tomar resolución en ellos»: la moral, la utilidad y la conveniencia, pero «la de útil y conveniente [es] la más fuerte y poderosa de todas por nuestra inclinación».

No cabe duda de que Álamos y Ribadeneyra muestran direcciones opuestas dentro del pensamiento político español. Aun así, comparten una serie de principios fundamentales. El más claro de ellos es que ambos aspiran a definir una monarquía. Aunque este hecho es evidente, permite evaluar de manera más precisa el tipo

ras pretendiesen inficionar y matar. Pero si algún Príncipe quisiese mantenerse de carne de víboras, y sustentarse con ponzońa, para prevenirse contra la ponzońa de su enemigo, tomaría la muerte por sus manos, y por matar a su enemigo, se mataría primero a sí» (285-286).

6. Sigo, en general, la lectura de Fernández-Santamaría sobre la simulación y la disimulación. Mario Prades Vilar critica un aspecto de su interpretación: la idea de que con esta defensa de la disimulación Ribadeneyra haría una concesión a las ideas de Maquiavelo. Para Prades Vilar, el jesuita se apoya en la tradición católica y especialmente en Martín de Azpilcueta, autor de Manual de Confessores et penitentes (1549), que fue adoptado en los cursos de casuística de la Compañía de Jesús. Pero tanto la disimulación como la práctica general de la Compañía, que supo emplear medios no muy piadosos para defender el catolicismo y fortalecer la orden, son concesiones tácticas que, aunque no podemos atribuir a Maquiavelo, conectan con el realismo que éste contribuyó a descubrir. 7. En el «Discurso para inteligencia de los aforismos», Álamos señala que el saber se alcanza al extraer reglas y principios universales de los hechos particulares, procedimiento del cual «formó Hipócrates, y los antiguos médicos que le siguieron, los principios de su ciencia por los sucesos de los enfermos particulares. Lo mismo hicieron Ptolomeo, y el resto de los primeros profesores de la Astrología». Álamos reconoce que la ciencia del Estado no puede compararse completamente con la astrología y la medicina, porque en el caso de la razón de Estado las reglas no son infalibles, pues la consecuencia de las acciones concretas puede variar debido al libre albedrío. Por ese motivo, sostiene que se trata de una ciencia predictiva que permite orientar la acción. 
de relación que mantienen con Maquiavelo. Como destaca Nicolai Rubinstein, en los Discursos sobre la primera década de Tito Livio el florentino entiende que la vida civil llega a su máxima expresión bajo una república. Esto no significa que Maquiavelo no defendiera en determinadas circunstancias la instauración de una monarquía, pero fija como modelo perfecto el republicano (Rubinstein 2006). En esta línea, y dentro de la voluminosa bibliografía sobre Maquiavelo, Maurizio Viroli destaca que en última instancia el florentino es uno de los últimos defensores de la política como arte del buen gobierno de las repúblicas, pues si bien El príncipe es un texto a favor del soberano, los Discursos se proponen describir cómo se puede convertir el stato de los Medici en una república (Viroli 2009: 212). Las críticas de Ribadeneyra a Maquiavelo y la elección que Álamos hace de la obra de Tácito deben comprenderse sin duda como dos actitudes distintas ante la concepción de la política que reveló el florentino, pues el primero rechaza la idea de que ésta se sitúa por encima de la moral y la religión, mientras que el segundo recupera el realismo y entiende que las acciones de un gobernante tienen que orientarse exclusivamente en función de la utilidad. Pero al lado de estas discrepancias podemos afirmar que ambos se alejan de la celebración republicana para reivindicar de manera plena la monarquía ${ }^{8}$. A conclusiones similares nos lleva el texto de Claude Lefort «Maquiavelo y la veritá effetuale». Como demuestra el autor, Maquiavelo postula que la efervescencia política de una república se encuentra en los tumultos que provocan la mayoría y en las concesiones que la capa dirigente se ve obligada a hacer. El florentino ataca la virtud y la religión porque entiende que el propósito de ambas es establecer un control ideológico que conjure el conflicto y mantenga al pueblo en obediencia (2007: 249). Nuevamente, la separación maquiaveliana de la política respecto de la moral y la religión tiene recepciones diferentes en Ribadeneyra y Álamos. Pero si este último retoma el realismo político, a través de Tácito reemplaza la propuesta republicana del florentino por la visión modélica de la Roma imperial. Álamos lo sintetiza al decir que «En las Repúblicas libres, hay que retirar las libertades poco a poco y no quitándolas todas de golpe» (37), y al afirmar que "A veces el remedio de una república dividida es reducirla al gobierno de uno solo" (67). Como subraya Álamos con estos aforismos, Tácito relata la transformación de la república en imperio y muestra el camino por el cual se asienta una monarquía?

8. Como destaca Peter Burke, las opiniones políticas de Tácito no son fáciles de discernir: «His ironic manner reveals a contempt for flattery and other forms of servility and also a certain impatience with theory, but leaves ambiguous his attitude to the Roman monarchy. Although he obviously disliked what went with it, Tacitus may well have regarded the institution as the lesser evil. As a result of his ambiguity he could be claimed as an ally by both the opponents and the supporters of monarchy in early modern Europe». En el caso de Álamos, está claro que se apoya en él para reinstalar el realismo político que puso al descubierto Maquiavelo como una forma mediante la cual defiende la monarquía. 9. Francesco Guicciardini ya lo había señalado en Ricordi politici e civili: «Insegna molto bene Cornelio Tacito a chi vive sotto e tiranni il modo di vivere e governarsi prudentemente, così com insegna a’tiranni e modi di fondare la tirannide» (1857: 87). 
Si Ribadeneyra y Álamos coinciden en esta defensa del sistema monárquico, también los une el hecho de que, el primero de manera abierta, el segundo con su llamativo silencio sobre el tema, fijan opiniones sobre los vínculos entre política y religión. Para dar cuenta de este aspecto hay que destacar que lo que ambos tienen como referencia es un Estado cuyos principios están fijados por lo que José Martínez Millán ha caracterizado como el proceso de confesionalización que se produce durante el reinado de Felipe II. Aunque se trata de un tema muy conocido, vale la pena recordar que ese enfoque, que abreva en las investigaciones de Ernest Walter Zeeden y Wolfgang Reinhar, cambia la mirada que se tenía sobre la Reforma y la Contrarreforma y plantea que en los territorios dominados por las tres confesiones (calvinistas, luteranos y católicos) se vivió una situación similar. Gracias a este proceso se definieron los dogmas y se logró la centralización política de las monarquías europeas a partir del uso de la religión como mecanismo para fijar los límites territoriales y establecer un control ideológico sobre la población (1995: 108). Felipe II puso en práctica un programa de ese tipo a través de un sistema de ideas y creencias intransigentes y un vasto cuerpo de reformas que estaba orientado a «nacionalizar» la Iglesia a través de la propuesta de que los generales fueran naturales de los reinos y mediante la aceptación de los acuerdos del Concilio de Trento, entre los cuales figura el importante decreto de residencia de los obispos en sus diócesis. Aunque los pensadores políticos no hacen mención expresa de estas cuestiones, piensan un Estado que posee estas características fundamentales. Se trata de una monarquía católica, con todo el peso que tiene ese concepto tras el reinado de Felipe II, y que adquiere un relieve aún mayor al contrastarlo con la defensa del conflicto republicano de Maquiavelo. Los libros de Ribadeneyra y Álamos pueden comprenderse como opiniones explícitas e implícitas sobre las relaciones que, en este marco, el Estado debe mantener con la religión.

Ribadeneyra elabora una posición nítida sobre este problema en Tratado del principe cristiano. Mario Prades Vilar destaca que el libro debe contextualizarse a partir de sus anteriores Historia del Cisma de Inglaterra y Tratado de la tribulación. En el primero, el jesuita retrata a los «maquiavélicos» Enrique VIII, Jacobo I e Isabel, que rompieron con la cristiandad y pusieron la religión al servicio de la política; en el Tratado de la tribulación Ribadeneyra explica la derrota de la Armada Invencible como un castigo indirecto de Dios al rey, que habría decidido la empresa por utilidad política y no para defender el cristianismo (2011: 138). En este marco, también hay que resaltar el realismo que siguió la Compañía de Jesús desde el momento mismo de su fundación. Como destaca Julián Lozano Navarro, los jesuitas se aferran a todo medio que encamine a la salvación de la sociedad y el fortalecimiento de la orden (2005: 31). Aunque esto no los convierte en maquiavélicos, mantienen una mirada realista sobre el mundo y son concientes de que muchas veces existe una separación entre medios y fines. Por esta vía sostienen la superioridad de la religión y demuestran en la práctica que la política posee cierta autonomía. Esto es particularmente claro en la importancia 
que le conceden a la casuística en el marco de la confesión como mecanismo concebido en parte para la conducción espiritual de los hombres de poder, pues gracias a los jesuitas éstos lograban «un tipo de confesor indulgente, hecho a medida para salvar su alma y del que dependen en buena parte su bienestar psíquico y muchos de sus comportamientos cotidianos» (Navarro Lozano 2005: 51). Más allá de que cuenta con importantes escritores políticos (Ribadeneyra, Botero, Francisco Suárez, Juan de Mariana, Juan Azor, Baltasar Gracián...), en la práctica de la Compañía se encuentra una posición nítida sobre la razón de Estado, en tanto los jesuitas entienden que los medios seculares son autónomos y a la vez están subordinados a Dios.

En este marco, hay que recordar que la Compañía de Jesús ocupó un lugar central en los conocidos forcejeos por las jurisdicciones cruzadas entre la monarquía y Roma. Como destaca Martínez Millán, la confirmación de la orden (1540), que incluye el famoso cuarto voto de obediencia al Papa, tiene como trasfondo el Saco de Roma por parte de las fuerzas imperiales en 1527 (2012: 36-37). Durante las decisiones centrales del confesionalismo de Felipe II la Compañía quedó, además, en el ojo de la tormenta ya que, contra la idea del Papa, el rey buscó integrarla en el proceso de reformas que estaba llevando a cabo a fin de nacionalizar la Iglesia. La solución provisoria del conflicto se encontró gracias a la elección de Gregorio XIV, cercano a España, acto que permitió que la Compañía conservara su forma de gobierno con el general como única cabeza y su dependencia del Pontífice a cambio de comprometerse a no actuar jamás contra el rey, imponer los estatutos de limpieza de sangre para el ingreso a la orden y reconocer a la Inquisición como única institución con poder para absolver a los herejes (Lozano Navarro 2005: 114-115). En esta tormentosa etapa, Ribadeneyra jugó un papel destacado. Como observa Miguel Gotor, al principio mantuvo contactos con el grupo de jesuitas pro-españoles, que apoyaban la «nacionalización" de Felipe II, pero se opuso a la escisión y se alineó con Roma, convirtiéndose en un mediador entre el general Claudio Aqcuaviva, la intransigencia espańola anti-romana y los padres italianos vinculados a la política pontificia (2012: 1013-1015). Dedicado a Felipe III, el Tratado del Príncipe Cristiano cristaliza este lugar complejo y presenta una cartografía de las acciones futuras que habría de realizar el soberano. Para Ribadeneyra, el poder de la monarquía proviene de Dios. Frente a la búsqueda de Felipe II de subordinar la iglesia al Estado, el jesuita establece, a lo largo de cuatro capítulos, que los temas religiosos son de exclusiva competencia eclesiástica y subraya que el Pontífice es la autoridad máxima en esta materia. Por este motivo, le asigna un lugar preponderante y sostiene que si el rey se equivoca debe arrodillarse ante él. Pero como a través de la disimulación acepta cierta autonomía de la política, que por otra parte está respaldada por la práctica de la Compañía de Jesús, le asigna una libertad relativa a la monarquía debajo de estos principios fundamentales.

Si Ribadeneyra propone una superioridad tanto espiritual como política de la religión, Álamos mantiene la subordinación espiritual, aunque manifiesta a la vez 
que el príncipe puede utilizar la religión con fines políticos. En primer lugar, comentando el pasaje en el cual Tiberio consagra templos a los dioses, recomienda que «El principal oficio del Príncipe, sea el cuidado de la religión, y de las cosas que tocan al culto divino, y reverencia suyas, haciendo y reedificando, y dotando templos, y más después de una victoria» (105). Sin embargo, establece también que «ninguna cosa ha de procurar tanto, como la Religión y honra de Dios, porque ninguna sentirán sus vasallos, como lo que de esta, y tuvieron sus padres, se les quitare» (11), propuesta que inclina levemente la religión dentro del ámbito de la conveniencia. Los pocos datos biográficos con los que contamos ayudan a darle mayor espesor a esta doble dirección ${ }^{10}$. En 1580 Álamos entra al servicio de Antonio Pérez y es encarcelado en 1587 por su relación con aquél. En 1598 es puesto en libertad por el duque de Lerma y se convierte en un colaborador de Olivares desde el comienzo de su valimiento. Probablemente inspiró el Gran Memorial de diciembre de 1624 y el Conde-Duque le confió el informe sobre el Consejo de Hacienda en 1625. Aunque no se pueden trasladar automáticamente las opiniones de Pérez y Olivares a Tácito español, esas figuras ayudan a darle relieve a la posición de Álamos sobre religión. Como destaca Carlos Puyol Buil (1994), el Conde-Duque era un católico ortodoxo, pero buscó subordinar todos los poderes fácticos al gobierno central, incluyendo entre ellos esa institución mixta que es la Inquisición. Inserto en este círculo, Álamos recomendaría una política semejante: la monarquía se encuentra subordinada espiritualmente a la religión, aunque el príncipe debe colocarse por encima de la iglesia.

Se puede argumentar que Tácito español no es del todo explícito en este sentido. Sí lo es, en cambio, Norte de principes. Aunque firmado por Antonio Pérez, Gregorio Marañón (1950) muestra pruebas sólidas que sugieren que el autor sería Álamos. Para no entrometernos en una cuestión de autoría, nos basta con saber que ese texto sale del círculo en el que éste se encuentra ${ }^{11}$. En esa obra se deben subrayar tres cuestiones de especial interés en este contexto. En primer lugar, está fuera de duda que la religión tiene una supremacía espiritual. Lo demuestran las constantes referencias a la Biblia y las numerosas protestas católicas que aparecen a lo largo del texto. En segundo lugar, hay que poner de relieve las recomendaciones que hace sobre la guerra en Flandes, que el autor piensa solo en relación con las necesidades del Estado, dejando de lado cualquier motivación religiosa. Por último, Norte de principes hace un detenido comentario sobre las jurisdicciones de la Iglesia en territorio español. El autor recomienda que el príncipe y su valido pongan especial atención en este asunto, ya que «se va entrando Roma mucho en la de España, y siendo tan gran parte de ella lo eclesiástico, y religioso, que ocupa más de la mitad de ella, cuando menos pensemos los habemos de hallar dueños de

10. Para estos datos, ver Carlos Puyol Buil (1993), Gregorio Marañón (1947), John Elliot y José De la Peña (1978).

11. Sigo, en este sentido, la propuesta de Julián Sauquillo (2008: 238-239). 
todo» (244-245). Con el propósito de limitar las propiedades de la Iglesia, Norte de principes recuerda que en la república de los hebreos los sacerdotes hacían usufructo de los diezmos, las primicias y las limosnas, pero no poseían bienes estables. A partir de esto, sostiene la necesidad de equilibrar las jurisdicciones, «no pasando de sus términos, ni tomando de lo que tiene la otra» (251). El círculo de Álamos afirma, de este modo, que el Estado es indisociable de la religión, pero impulsa al monarca a que defienda sus jurisdicciones y limite las de Roma. Frente a la visión de Ribadeneyra, recupera de manera plena el realismo político que descubre Maquiavelo, reformulándolo a partir de una defensa irrestricta de la monarquía y manteniendo una ambivalencia en materia religiosa, que obliga al príncipe a someterse espiritualmente a la religión y a mantenerse por encima de la estructura eclesiástica.

\section{Razón, moral, religión}

Sobre la base de una serie de principios compartidos (la defensa de la monarquía y la subordinación espiritual de la razón de Estado a la religión), Ribadeneyra y Álamos dibujan el espectro dentro del cual se mueve el pensamiento político del siglo XVII. Este espectro puede comprenderse a partir de los conceptos de razón, moral y religión. Ribadeneyra establece una rearticulación ortodoxa de estos términos y por esa vía reconoce solo una autonomía restringida a la política a través de una disimulación controlada. Del otro lado, Álamos acepta que la política está subordinada a la religión, pero restringe esa subordinación al ámbito espiritual, de modo que fractura la razón de Estado respecto de los principios morales, no tanto porque recomiende un accionar hipócrita (ni Tácito ni él lo hacen), sino porque comprende la acción política a partir de la conveniencia y los efectos que producen las decisiones del príncipe a fin de conservar el Estado. En Álamos, el tacitismo sería una forma de asumir el realismo político para el ámbito de una monarquía católica. Inicialmente, varios de los principales tratadistas posteriores se ubican cerca de Ribadeneyra. Pero a medida que transcurre el siglo buscan amplificar la autonomía y se acercan progresivamente a la perspectiva que Álamos y Pérez presentan en Nortes de príncipes y Tácito español.

Pedro Barbosa Homen es un buen ejemplo del punto de partida al que acabo de hacer referencia. En Discursos de la jurídica y verdadera razón de Estado (1629), el autor separa las esferas del monarca y el Papa. Para Barbosa, «el último fin de la potestad eclesiástica es la beatitud sobrenatural», mientras que el propósito de la potestad temporal «es la beatitud solamente natural, que consiste en lo que es virtuosa, y bienaventuradamente vivir en este mundo inferior» (presupuesto III, artículo II). Aunque están separadas, para Barbosa estas esferas mantienen dos tipos de vínculos fundamentales. En primer lugar, la religión le marca un non plus ultra a la acción política. Si bien el Papa tiene un ministerio espiritual, todavía queda en él suficiente potestad como para exigirles a las cabezas de Estado que mantengan la finalidad de la salvación como propósito central del gobierno. Si esto no se cumpliera, está en condiciones de «privar de los reinos a los mismos reyes, y príncipes, o darles 
coadjutores». En segundo lugar, Barbosa establece un sistema conceptual que conecta el mundo secular con el religioso: la política verdadera es la que se ajusta a las virtudes morales, las virtudes morales se aprenden con el auxilio de la razón natural y la razón natural se ajusta al programa divino. La buena razón de Estado, que el autor opone a la de Maquiavelo, es aquella que mantiene en orden concéntrico estas esferas.

Para conseguir esta solución, Barbosa sigue un modelo escolástico. Parte de principios generales y llega a las ideas particulares mediante un sistema deductivo. Hacia mediados de siglo, Diego Saavedra Fajardo y Baltasar Gracián invierten el orden y toman como punto de partida la política concreta. En cierta medida, este cambio de enfoque se puede explicar por el estilo. Como demuestra Jorge García López (2001), Saavedra y Gracián continúan la prosa lacónica de Il Romulo (1629). La obra de Virgilio Malvezzi, traducida por Francisco de Quevedo en 1632, terminó de definir una identificación entre Tácito, laconismo y discurso político que ya estaba en ciernes en Álamos. Enrolados en esta línea, Saavedra y Gracián siguieron la práctica de redactar máximas y aforismos, concepto este último que el autor de Tácito español presenta en una de las introducciones de su $\mathrm{obra}^{12}$. Esta opción estilística se corresponde con la forma mediante la cual piensan la razón de Estado. Aunque utilizan los mismos conceptos de Barbosa, reflexionan sobre la política a partir de modelos o ejemplos concretos y de esa forma cambian el orden seguido en el encadenamiento conceptual: las acciones del príncipe deben estar reguladas por la razón, la razón se ajusta a la moral y la moral remata en el catolicismo. Si de este modo mantienen la subordinación de lo político a lo religioso, la forma mediante la cual abordan el problema les permite conferirle una autonomía más amplia al Estado. Como complemento de esta dirección, Saavedra y Gracián entienden que el poder político se ejerce sobre lo que hoy en día llamaríamos la psicología de las personas. Para ambos, aunque de manera más clara para Saavedra, la razón, la moral y la religión operan sobre la naturaleza humana.

El punto de partida de Empresas políticas (1640/1642) se encuentra, precisamente, en una distinción entre naturaleza y razón ${ }^{13}$. Para Saavedra, la naturaleza

12. En el «Discurso para inteligencia de los aforismos», Álamos comenta que toma ese nombre de Hipócrates y Ptolomeo y por esa vía intenta subrayar el carácter científico de la política. En este sentido, se trata de un texto capital para los conocidos cruces entre política y medicina que se producen en el siglo XvII.

13. La obra conoció dos ediciones, la primera de 1640 y la segunda de 1642. Jorge García López (1998) destaca que los cambios más significativos se encuentran en que en la segunda versión el autor hace una corrección religiosa de la primera. En el texto de 1640 Saavedra declara que las máximas de su obra tienen como fuente los Anales de Tácito, mientras que en el de 1642 añade que sus enseñanzas están evaluadas a partir de las letras sagradas. Para García López, el verdadero espíritu de Empresas políticas se encuentra en el tacitismo de la primera versión, pues juzga que con las correcciones el texto se vuelve contradictorio. De acuerdo con la perspectiva que he trazado en este trabajo, este doble apoyo de Saavedra viene a demostrar que uno de los temas que aborda en Empresas politicas es de qué modo han de articularse esos dos órdenes disímiles que son los de la política y la religión. 
del hombre está compuesta por apetitos que se vuelven perniciosos si no reciben una conducción adecuada. Incluye en esa categoría el amor, la ira, la esperanza y el miedo, pero a lo largo de su texto la naturaleza gana en complejidad, abarcando también el impulso del hombre hacia el egoísmo, la maldad, la mentira y la libertad. Con este concepto amplio, Empresas políticas deja de lado la discusión sobre la buena o la mala razón de Estado. Para Saavedra, la simulación, la maldad, el egoísmo, todo aquello que transforma al príncipe en un tirano, no es producto de la razón, sino de una naturaleza descontrolada. En la empresa 7 se refiere a la «tiranía de nuestras inclinaciones y apetitos» (117) y poco después aclara que «Si se viese el ánimo de un tirano, se verían en él las ronchas y cardenales de sus pasiones» $(118)^{14}$. Esto le permite resolver el desafío de la obra de Maquiavelo. En El príncipe, éste recomienda que la conducta del gobernante sea virtuosa y se ajuste a la razón, pero como a menudo debe obrar como los animales, propone los modelos del león, que tiene fuerza y puede vencer al lobo, y de la zorra, que posee la inteligencia del engaño y no cae en las trampas que le tienden. En este famoso capítulo XVIII, Maquiavelo se desliza de una manera sutil, porque por una parte mantiene la idea de que la razón y la virtud son indisociables, mientras que por la otra demuestra un quiebre entre esos dos órdenes en lo que respecta a la práctica del gobierno, ya que para conservar el Estado es necesario un arte que se independice de la moral y esté dispuesto a la mentira. En la empresa 43 Saavedra critica estas ideas a partir de los supuestos iniciales de Maquiavelo: el engaño no pertenece al ámbito de la razón, sino que es una pasión propia de la naturaleza. Si bien los hombres pueden aprender de los animales, no es conveniente que los imiten, pues «sería hacer injuria a la razón, dote propio del hombre, con que se distingue de los demás animales» (402).

Para Saavedra, la razón es un mecanismo para sofrenar la tiranía de la naturaleza. Pero en Empresas políticas presenta dos visiones levemente diferentes del concepto. En primer lugar, y como se desprende de su idea de que la naturaleza es la fuente de todos los vicios, establece una equivalencia entre razón y moral. Para Saavedra, el príncipe debe crear leyes justas y diseñar y conservar buenas constituciones, de modo que tiene que castigar los delitos por igual y distribuir los bienes según los merecimientos. Pero en el ámbito del Estado la razón también es un arte para evaluar las circunstancias y decidir cuándo y por qué vías es conveniente la aplicación de los principios morales. En la empresa 22 Saavedra hace una serie de recomendaciones para el castigo de los delitos que está planteada a partir de esta concepción realista de la política. Cuando el reino está ordenado, al príncipe sólo le alcanza con que sus ministros apliquen la justicia, pero cuando impera el desorden y se ha perdido el respeto a las leyes es necesario «templar el rigor [...] porque si la virtud sale de sí, impaciente de los desórdenes,

14. Enseguida añade que en el pecho del tirano «se levantan tempestades furiosas de afectos, con los cuales, perturbada y ofuscada la razón, desconoce la verdad» (118). 
y pone la mano en todo, parecerá crueldad lo que es justicia» (242). En el príncipe, existe una leve separación entre razón y moral, pues aunque debe seguir el horizonte de la virtud, está obligado a evaluar las circunstancias antes de decidir sus acciones ${ }^{15}$. Por esta vía, Saavedra profundiza la autonomía de la política: el príncipe está obligado a observar la conveniencia en la aplicación de las leyes, pues lleva las de perder el dogmático que no sabe adaptarse a las circunstancias y sólo tiene éxito aquél que tolera ciertos males a fin de conducir progresivamente a los súbditos hacia el bien.

Saavedra utiliza un procedimiento similar para comprender los vínculos entre política y religión. El punto de partida de su propuesta es separar los dos ámbitos de manera nítida. Como demuestra Jesús Villanueva, en su obra sostiene que la educación del príncipe debe basarse en las virtudes heroicas y durante su gobierno tiene que orientarse a partir del modelo de sus mayores y en pos de la fama como bien que necesita alcanzar ${ }^{16}$. Esto significa que la ética del gobernante no puede coincidir de ninguna manera con la ética del sacerdote. Sin embargo, establece entre ambas esferas una serie de articulaciones fundamentales. En primer lugar, recuerda de manera recurrente que Dios es la fuente de la soberanía. Esto significa que la religión se convierte en el non plus ultra de la política (como sostiene en la empresa 4, lo primero que debe enseñársele al futuro soberano es el temor a Dios). En segundo lugar, para Saavedra Dios es la fuente de la cual brota de manera pura la luz que le da sentido a las acciones y a partir de la cual se discierne el bien y el mal, el error y la razón. En la empresa 18 presenta la imagen de un cetro que remata en la parte superior en una media luna que mira al sol. El sol representa a Dios y la luna al príncipe, de modo que éste debe mantenerse a partir de la luz que le otorga aquél. En la misma empresa recuerda que los egipcios grababan en la punta de los cetros la cabeza de una cigüeńa, «ave religiosa y piadosa con sus padres, y en la parte inferior un pie de hipopótamo, animal impío e ingrato a su padre, contra cuya vida maquina por gozar libre de los amores de su madre» (205). Con estas dos imágenes, pone de manifiesto que la razón y la virtud, en términos absolutos, tienen su fuente en Dios. Pero a la vez, y en tercer lugar, Saavedra apela a la religión para justificar la excepcionalidad que le corresponde al príncipe en lo que respecta a los vínculos entre razón y moral. En la misma empresa 18 sostiene que «La mayor perfección de su

15. Así, Saavedra recomienda en general el castigo y el rigor sobre los delitos de unos pocos y la tolerancia de los delitos menores de la mayoría. En este campo, defiende incluso el asesinato en secreto que Tiberio hace de un esclavo que fingía ser Agrippa por lo conveniente que fue en relación con la amenaza de revueltas que podía implicar un castigo público.

16. Según Jesús Villanueva, Saavedra se coloca en el centro de una tensión entre la realidad corrupta y los principios de la moral cristiana, de modo que compone un modelo para que el príncipe se forme «en la práctica de las "virtudes heroicas" que corresponden a un gobernante» y se esfuerce «en superar la timidez y el encogimiento que el aislamiento y una excesiva escrupulosidad en materia de religión podrían producir» (1998: 187). 
virtud consiste en satisfacer a las obligaciones de príncipe que le impuso Dios» $(210)^{17}$. Estas obligaciones lo desvinculan de la moral del religioso y de la de los particulares, pero apuntan también a que el príncipe tiene que conocer y utilizar la diferencia que existe entre los principios y la razón. En Saavedra, la política se independiza de la religión justamente porque así lo dispone Dios.

\section{Virtud secular}

Baltasar Gracián comparte con Saavedra el mismo esquema conceptual. En El político destaca que el arte de gobierno es un saber específico que no se confunde ni con la religión ni con los saberes de los particulares. Aunque no las enumera con prolijidad, destaca tres fuentes de las que brota este saber. La primera de ellas se encuentra en las condiciones particulares de los gobernantes. Refiriéndose a la capacidad como clave para el gobierno, Gracián afirma que «Nace, no se adquiere el dado óptimo, el don perfecto, que desciende del padre de las ilustraciones» (I, 69-70). La segunda de las fuentes del saber político es la formación de los futuros soberanos. Para Gracián, el príncipe tiene que recibir una educación heroica orientada por la emulación de sus mayores. La tercera de estas fuentes es la experiencia, concepto que circunscribe a la capacidad que tiene el gobernante de saber actuar según lo pidan las circunstancias, y que tiene su punto máximo en la elección de la paz o la guerra como lineamientos predominantes de un reinado: «En un tiempo se desea un príncipe guerrero, y en otro un pacífico; la infelicidad está en trocarse las veces, en encontrarse las contingencias» (I, 64). Sobre la base de estas tres fuentes, Gracián afirma la especificidad del saber político y por esa vía establece que pueden existir príncipes que aunque tienen "grandes vicios de hombres» poseen "grandes virtudes de reyes» (I, 60).

Como en Saavedra, este saber mantiene relaciones complejas con la religión. Por una parte, Gracián entiende que el gobernante no puede confundirse con el religioso. Según sostiene en El político, «Religiosísimo fue Graciano, pero más para una celda que para la silla imperial. El aragonés Ramiro, y el portugués Enrico, eran más para el coro que para el trono» (I, 60). Aunque no abunda en explicaciones, está claro que Gracián deslinda el saber político de las obligaciones del religioso y por esa vía separa Iglesia y Estado. Esta independencia se hace patente al tomar en cuenta que en su breve tratado pone como modelos a gobernantes católicos junto a reyes de la antigüedad pagana y aun a príncipes del orbe musulmán ${ }^{18}$.

17. Poco antes señala: «en el príncipe son convenientes aquellas virtudes heroicas propias del imperio, no aquellas monásticas y encogidas que le hacen tímido, embarazado en las resoluciones, retirado del trato humano, y más atento a ciertas perfecciones propias que al gobierno universal» (210). 18. Por este motivo, en El Político usa ejemplos que habrían alarmado a Ribadeneira: al lado de los grandes príncipes católicos recuerda con encomio a reyes de la antigüedad pagana y del mundo musulmán. Cito los textos de Gracián por las Obras completas, indicando el tomo en números romanos. 
Pero aunque la concibe autónoma, Gracián subordina la política a la religión. En las páginas conclusivas de El político sostiene que Fernando el Católico «Conquistó reinos para Dios, coronas para tronos de su cruz, provincias para campos de la Fe; él fue quien supo juntar la tierra con el cielo» (I, 69). Poco antes elogia a Luis IX de Francia y se lamenta de la situación actual:

Sacó el Santo rey la connatural guerra de Francia, y echóla sobre los enemigos del Señor, con gran gloria del cristianísimo renombre; sacóla él y volviéronla sus sucesores, sin haber vuelto a salir jamás, ya de los propios, ya de los cristianos confines, con tan poco fruto como felicidad, que a haberla proseguido, estuviera ya olvidado en toda Europa, en África y en Asia el nombre de Mahoma. ¡Oh punto digno de observarse y de lamentarse también! ¡Que esté hoy ardiéndose en guerras el cristianismo, y descansando todo el paganismo! ¡Bañada en sangre la cristiandad, y en rosas la infidelidad! (I, 68).

Con estas palabras, Gracián establece dos tipos de vínculos de la política con la religión. En primer lugar, ésta vuelve a funcionar como un non plus ultra para la acción. En segundo lugar, según el esquema usual de la Compañía de Jesús, Gracián subordina los medios seculares, que tienen una gran especificidad, a los fines religiosos. En su obra, esta finalidad se encuentra planteada tanto en relación con la política interior como con la exterior. En cuanto a la primera, destaca que uno de los mayores logros de Fernando el Católico fue la expulsión de los judíos, la derrota de los moros y la creación del Santo Oficio ${ }^{19}$. En el escenario externo, como se ve en las palabras recién citadas, la defensa de la religión se vuelve una cuestión igual de central. El contexto histórico en el que redacta El político le da mayor fuerza a esas palabras: la alianza de Francia con Suecia y los holandeses en contra de los Habsburgo, producida poco después de la Paz de Praga, que disuelve los propósitos religiosos de la Guerra de los Treinta Años y enfrenta de manera descubierta a Francia y España. Lo mismo se encuentra en «El museo del discreto». En ese pasaje de El Criticón rechaza a Maquiavelo y Jean Bodin, reivindica a Botero y destaca como «riquísima joya» el «Testamento político del Emperador» (II, 513-514). En ese texto, Carlos V recomienda a Felipe II que someta sus acciones a la voluntad de Dios y cuide la observancia de la fe. En caso de abusos por parte del Pontífice, le aconseja que haga valer sus derechos sin escándalos. Con la exaltación de este texto y con el reproche que hace a la secularización de la guerra, Gracián explicita uno de los andariveles por los que se movió la Compañía de Jesús: las decisiones en política exterior deben estar subordinadas a la defensa de la catolicidad.

Pero aunque piensa dentro del mismo esquema conceptual de Saavedra, Gracián produce algunas innovaciones de particular interés para el pensamiento

19. «Lo que todos éstos hicieron en la monarquía de Italia, obró Fernando solo en la de España. Él la hizo religiosa con purgarla de unos y otros infieles y con ensalzar al Tribunal Sacro y vigilante de la Inquisición» (I, 89). 
político español. Ante todo, presenta una mirada mucho más rigurosa sobre las relaciones entre razón y moral. Esto se puede percibir a partir de la particularidad discursiva que tiene El político. El breve tratado de Gracián no es exactamente un libro sobre razón de Estado. En él no se propone describir la naturaleza del poder ni redactar máximas que orienten las decisiones del gobernante, sino que busca enumerar las virtudes de Fernando el Católico. Esas virtudes (fue un "príncipe comprensivo, prudente, sagaz, penetrante, vivo, atento, sensible, y en una palabra, sabio» (I, 73)) no se aprenden, sino que nacieron con él. A pesar de que la política es un saber práctico, Gracián no se propone enseñar nada concreto, como sí lo hacen Barbosa, Saavedra y Álamos; con El político aspira, más bien, a presentar un modelo intachable a fin de ocupar un lugar en la educación de los gobernantes, porque muestra un horizonte a seguir, de modo que puede incitar a quien lo lee a emular "los brillantes rayos de la virtud y el honor» (I, 51). Por este camino, Gracián refuerza la idea de que la verdadera política debe tener como horizonte el vínculo perfecto entre razón y moral. Pero, al hacerlo a partir de Fernando el Católico, refuerza la autonomía, pues demuestra que las virtudes del gobernante se encuentran representadas por un hombre del mundo secular. En este sentido, Gracián profundiza la idea de Barbosa de que la política persigue una beatitud solamente natural.

Paradójicamente, esta visión rigurosa y secularizada de la virtud se basa en la cuña que ha separado los conceptos de razón y moral. En Oráculo manual, que constituye un texto fundamental para advertir esta cuestión, Gracián sigue una marcha fluctuante que repara, por una parte, en una defensa irrestricta de la virtud y, por la otra, en una concesión realista a la flexibilidad a la que está obligado el hombre para enfrentarse a las circunstancias concretas. La primera de estas tendencias tiene su cúspide en las reflexiones sobre la sindéresis, cuyo centro se encuentra en el aforismo 96. Desde luego, la sindéresis es el conocimiento de los principios fundamentales de la moral. En el aforismo 96 agrega que «Todas las acciones de la vida dependen de su influencia, y todas solicitan su calificación» (II, 152). De este modo, convierte el concepto en el ajuste fundamental entre razón y moral: «Consiste en una connatural propensión a todo lo más conforme a razón, casándose siempre con lo más acertado" (II, 152) ${ }^{20}$. Para Gracián, la razón empalma con la moral y propone como héroe a aquél que no deja el camino que es a la vez recto y verdadero. Pero en Oráculo manual y El Criticón presenta una imagen pesimista sobre el hombre y el estado actual de la sociedad. Se refiere en ambos textos a la tiranía de la naturaleza humana y encuentra que el mundo está dominado por el

20. En el 60 se refiere a los que nacen prudentes, que «entran con esta ventaja de la sindéresis connatural en la sabiduría», y gracias a la edad y la experiencia «llegan a un juicio muy templado» (II, 141). En el 168 critica a «los desvanecidos, presuntuosos, porfiados, caprichosos, persuadidos, extravagantes, figureros, graciosos, noveleros, paradoxos, sectarios y todo género de hombres destemplados», señalando que «Donde falta la sindéresis, no queda lugar para la dirección» (II, 176). 
imperio de la mentira. En este sentido, entiende que han pasado los tiempos de la concordia: la sociedad es una lucha de todos contra todos y el hombre debe "Confiar en los amigos de hoy como enemigos del mañana» (II, 192) ${ }^{21}$. Por este motivo, Gracián distingue razón y moral y se hace eco de la máxima de Maquiavelo del león y la zorra: «Cuando no puede uno vestirse la piel del león, vístase la de la vulpeja [...] por un camino o por otro, o por el real del valor o por el atajo del artificio. Más cosas ha obrado la maña que la fuerza, y más veces vencieron los sabios a los valientes» (II, 193).

Esta marcha fluctuante de Oráculo manual indica que Gracián comprende que la razón y la moral son conceptos distintos que sin embargo deben estar relacionados. En este sentido, sostiene que el hombre debe ser un mixto de serpiente y paloma, según establece en el aforismo 243, lo cual le permite estar prevenido contra los engaños, dominar la naturaleza y acomodarse a la ocasión. De acuerdo con esto, busca un término medio, que es el que permite mantener ligadas la inteligencia con las obligaciones éticas: «No ser tenido por hombre de artificio, aunque no se pueda ya vivir sin él. Antes prudente que astuto. Es agradable a todos la lisura en el trato, pero no a todos por su casa. La sinceridad no dé en el extremo de simplicidad, ni la sagacidad de astucia» (II, 193). La clave de sus argumentos se encuentra en el deslinde tradicional entre simulación y disimulación:

Sin mentir, no decir todas las verdades. No hay cosa que requiera más tiento que la verdad: que es un sangrarse del corazón. Tanto es menester para saberla decir como para saberla callar. Piérdese con sola una mentira todo el crédito de la entereza: es tenido el engańado por falto y el engańador por falso, que es peor. No todas las verdades se pueden decir: unas porque me importan a mí, otras porque al otro (II, 180).

Con esta visión realista de la virtud Gracián le impone una segunda transformación al pensamiento político español. Como demuestra Elena Cantarino (2011), saca la razón de Estado del ámbito del príncipe y la convierte en un arte para el comportamiento de los hombres en general. En El héroe (1637), y lo mismo vale para El discreto y Oráculo manual, le comenta al lector que su propósito es exponer «una razón de estado de ti mismo, una brújula de marear a la excelencia, un arte de ser ínclito con pocas reglas de discreción» (I, 3) 3$)^{22}$. Esta amplificación

21. Como dice Maravall en términos generales, «el moralista del Xvir considera al individuo empeñado en una lucha de todos contra todos, cuya imagen puede universalizarse en todos los órdenes y de la que deriva la agresividad con que los individuos se combaten también recíprocamente» (1975: 170). En lo que respecta a El Criticón, Aurora Egido ha demostrado que la obra pone al descubierto el desfase entre la idea armónica del gran libro del mundo y la dura realidad que a cada paso se encuentran los personajes, de modo que, en el texto, «La experiencia vital, en desacuerdo con la idea, transforma la armonía del mundo en caos y el ser en apariencias» (1986: 44).

22. Como destaca Antonio Pérez Lasheras, Gracián escribe «tratados en los que se trata de abordar los distintos aspectos para formar al hombre de su tiempo» (2010: 456). 
del concepto tiene consecuencias importantes que se pueden notar al comparar su obra con la de Saavedra. En Empresas políticas, éste sostiene que «En los particulares es doblez disimular sus pasiones. En los príncipes, razón de Estado» (121). Con esto, Saavedra destaca que el gobernante se encuentra en una situación excepcional. Mientras que en los particulares la disimulación es una hipocresía condenable, en el gobernante se vuelve una obligación, porque tiene que percibir la diferencia que existe entre razón y moral para cumplir con el mandato de Dios de gobernar. La excepcionalidad de la política tiene por consiguiente un fundamento religioso. $\mathrm{Al}$ extender el alcance de la razón de Estado, Gracián suprime la excepcionalidad moral y elimina el fundamento religioso. Por esta vía, empuja el pensamiento político a una mayor secularización: las decisiones que toman el príncipe y los particulares operan en el juego que se establece entre los medios complejos de la sociedad y el horizonte de una moral laica que empalma con la religión pero que en modo alguno se reduce a ella.

Los alcances de esta secularización han sido explorados a partir del aforismo 251 de Oráculo manual: "Hanse de procurar los medios humanos como si no hubiese divinos, y los divinos como si no hubiese humanos» (II, 203). Para José Antonio Maravall (1975) y Aurora Egido (1997), el autor abandona las justificaciones religiosas y elabora una política enteramente laica. Antonio Rivera García (2011) demuestra, por el contrario, que con este aforismo pone de manifiesto la tendencia general de los jesuitas de transformar el catolicismo en una religión moral. Gracián evidentemente sigue este camino, pero al hacerlo profundiza la separación del mundo secular respecto del mundo religioso. Cuando afirma que «Hanse de procurar los medios humanos como si no hubiese divinos, y los divinos como si no hubiese humanos", debemos entender, en este sentido, que la salvación únicamente se encuentra por medio de un comportamiento virtuoso, de modo que no puede invocarse la intervención divina para santificar acciones condenables desde el punto de vista moral. En un sentido positivo, el aforismo demuestra que las acciones del hombre deben estar orientadas por la sindéresis. Ésta conecta con lo religioso, pero se vuelve específica de lo secular. En el último aforismo de Oráculo manual lo resume: la virtud es el «sol del mundo menor, y tiene por hemisferio la buena conciencia; es tan hermosa, que se lleva la gracia de dios y de las gentes» (II, $217)^{23}$. Como se puede ver, conecta con lo religioso, porque la religión es, como en Saavedra, el eslabón que cierra el sistema conceptual, pero lo hace a partir de una visión laica de la moral que opera exclusivamente en el ámbito secular ${ }^{24}$.

23. En El comulgatorio agrega que «poco valen los humanos medios sin los divinos» (III, 381). 24. En el último aforismo de Oráculo manual señala que el hombre debe tomar como modelo al santo. Pero el santo que presenta no es una figura que adorna el cielo, sino un modelo de comportamiento para el hombre discreto. Para Gracián, éste debe ser «prudente, atento, sagaz, cuerdo, sabio, valeroso, reportado, entero, feliz, plausible, verdadero y universal héroe» (II, 217). Incluso la causa final está situada en este mundo: muerto, se lo reconoce porque se convierte en un hombre memorable. Lo mismo se advierte en El Criticón. Al morir, los personajes ingresan 
Si volvemos atrás, podemos decir que el pensamiento político se mueve desde Ribadeneyra y busca un término medio al aceptar de manera controlada la diferencia que Álamos había planteado entre razón y moral. El punto de llegada de este proceso se encuentra en Comentarios politicos a los Annales de Cayo Vero Corneli Tácito (1687). En esa obra poco orgánica, José Alfonso Lancina se mantiene dentro del sistema intelectual del Barroco: subordina la monarquía a la religión y mantiene la idea de que el rey le debe al Papa «suma veneración» (115). Pero la separación del mundo secular y el divino termina de alejar el pensamiento político de la posición ortodoxa de Ribadeneyra para acercarlo a las ideas que Álamos había mantenido en Tácito español. Con sus propios comentarios a los Anales, Lancina efectivamente libera las reflexiones sobre la razón de Estado y coloca la acción política por encima de la moral de los particulares y las manifestaciones externas de lo religioso.

El primer punto salta a la vista al contrastarlo con los tratadistas anteriores. Si en Saavedra y Gracián el príncipe debe tener presente las condiciones bajo las cuales gobierna y por lo tanto está obligado a evaluar las circunstancias a la hora de aplicar la justicia, en Lancina esa concesión al realismo se convierte en clave para el gobierno, de modo que fractura ahora definitivamente los vínculos entre razón de Estado y moral: «Para vivir sabiamente de particular bastan las virtudes morales, pero se necesita otras artes para dirigir a otros, y mantener un reino» (93). Esto tiene un sentido distinto en los tiempos de paz y en los tiempos de guerra. En los primeros, Lancina concede que la justicia y la honestidad contribuyen al éxito del gobierno, pero en los momentos de peligro la política puede y debe moverse libremente a fin de mantener el Estado: «La razón de estado hace muchas cosas lícitas, que en otra ocasión serían reprobadas; cuando se hallan desconcertadas las materias sería imprudencia obrar con regla» (69).

En cuanto a la religión, Lancina sigue el mismo patrón. Si bien pone de manifiesto que la política está subordinada a Dios y que los príncipes le deben entera obediencia al Pontífice, estas advertencias se limitan a la obligación de los soberanos de mantenerse dentro de la religión presidida por el Papa, evitando la tentación de los cismas al estilo anglicano. Por debajo de este deber, el rey necesita moverse con plena autonomía. Esto significa que puede usar la religión

a la mansión de la eternidad. En ese punto, Gracián abandona la pluma: «Lo que allí vieron, lo mucho que lograron, quien quisiere saberlo y experimentarlo, tome el rumbo de la Virtud insigne, del Valor heroico y llegará a parar al teatro de la Fama, al trono de la estimación y al centro de la Inmortalidad» (III, 371). Javier García Gibert destaca que la tercera parte de El Criticón tiene doce capítulos, mientras que las dos anteriores tienen trece. Para el crítico, «Gracián elude hablar del Cielo, del paraíso de los cristianos -igual que si no existiera-, pero el diseńo estructural de su novela, su esperada simetría, lo convoca aún con más fuerza, con mayor perentoriedad, en este último y omitido capítulo ausente» (1998: 75). Si el paraíso opera sobre la novela y la obra toda de Gracián, lo hace como una fuente que se ha vuelto irrepresentable. La virtud tiene su norte en la religión, pero el hombre debe actuar teniendo en cuenta los caminos visibles del mundo secular. 
para ejercer y ampliar su dominio sobre la población. Para él, los actos piadosos del soberano no tienen una finalidad católica, sino que buscan despertar la admiración de los súbditos. A Lancina le parece digno de admiración que cuando Carlos II encuentra el Sacramento de la Eucaristía deje su carroza y ponga los pies en el barro, no porque se trate de un acto piadoso, sino porque de ese modo se granjea al vulgo (83). En sintonía con esto, aconseja mantener al pueblo en la mayor ignorancia posible. Esa idea, que ya había aparecido en Saavedra, tiene ahora una utilidad que para éste sería inadmisible: gracias a esa ignorancia el soberano puede tomar cualquier prodigio natural y amenazar con que se trata de una señal de Dios a fin de mantener el dominio sobre la población (224). No es de extrañar, en este contexto, que reproche la expulsión de los judíos y los moros. Mientras Gracián celebra esas decisiones, Lancina las mira sin pasiones religiosas y considera que significaron un serio deterioro a las finanzas del Estado.

\section{Jurisdicciones y poder}

El pensamiento político del siglo xvII es un sistema intelectual que tiene como propósito procesar en clave monárquica, y con diferentes grados de crítica y aceptación, la crisis entre política, moral y religión que puso en evidencia Maquiavelo a principios del xvi. Aunque varios de los tratadistas recién estudiados condenan al florentino por impiadoso, las críticas de Barbosa, Saavedra y Gracián demuestran que esa crisis es menos la opinión de un escritor que la realidad palpable que se registra en el ejercicio concreto del poder. A partir del reconocimiento de este hecho, podemos decir que el rechazo de su obra se basa en dos causas centrales: los tratadistas se separan de él porque buscan rearticular el realismo político con la moral y la religión y porque defienden una monarquía que gracias al proceso de confesionalización ha logrado establecer un control social efectivo. Sobre esta base, el ciclo de la razón de Estado se muestra a la vez estático y dinámico. Es dinámico porque la crisis que los tratadistas buscan solucionar los lleva a dar soluciones que dibujan una línea sostenida hacia la secularización; es estático, porque los límites del debate están fijados de antemano por el problema que intentan resolver: ¿qué vínculo existe entre política y religión? De este modo, el pensamiento político incurre en una petición de principio, pues la pregunta los lleva a dar una respuesta en la que siempre la religión ocupa un lugar central. De Ribadeneyra a Lancina, la razón de Estado define una estrategia general (la subordinación de la política a la religión) y propone una serie de respuestas tácticas en su interior. Éstas se pueden describir a partir de los vínculos entre razón, moral y religión. Mientras Ribadeneyra busca reestablecer de manera ortodoxa las relaciones entre esas esferas, Álamos define la monarquía a partir de la subordinación espiritual de ésta a la religión y mediante la idea de que la política se mueve en un terreno autónomo cuyos objetivos están planteados de manera exclusiva por la conveniencia y la utilidad. Si bien Barbosa, Saavedra y Gracián en principio toman como punto de partida la concepción que ejemplifica Ribadeneyra, delimitan cada vez con mayor precisión los términos a 
fin de legitimar las reglas de la política y definir la cuota de realismo justificable para gobernar. Lancina es un punto de llegada: separa razón y moral y reivindica una autonomía plena de la política sin salir de la subordinación de ésta a Dios.

Por el hecho mismo de afrontar las relaciones entre el mundo secular y el mundo divino, la razón de Estado es un discurso que se dedica a indagar los problemas jurisdiccionales y las relaciones entre los poderes reales de la monarquía y Roma. En este aspecto, Ribadeneyra y Álamos proponen abordajes contrarios: el primero defiende la prioridad de Roma en tanto pone de manifiesto que los asuntos teológicos le corresponden exclusivamente a la Iglesia y sostiene que el príncipe debe arrodillarse ante el Pontífice si ha olvidado la defensa del catolicismo como prioridad, mientras que Álamos y Pérez postulan la necesidad de que el príncipe restringa las jurisdicciones y se alcance un equilibrio en este sentido. Como sucede con las definiciones conceptuales, el pensamiento político sigue en esta materia un movimiento que va de las ideas de Ribadeneyra a las del autor de Tácito español. Barbosa radicaliza la posición del jesuita, en tanto considera que el Pontífice está en condiciones de quitarle la soberanía al rey. Saavedra y Gracián, en cambio, se inclinan a la búsqueda de un término medio en esta materia.

En la empresa 24, el primero explicita con claridad la voluntad de encontrar un equilibrio en el estado actual del entramado jurisdiccional: «Distintos son entre sí los dominios espiritual y temporal. Éste se adorna con la autoridad de aquél, y aquél se mantiene con el poder de éste» (266). La posición de Saavedra es más compleja cuando aborda cuestiones puntuales, como la Inquisición, a la que no nombra pero de la que habla de manera visible. El Santo Oficio es uno de los ejes en los que se visualiza la superposición jurisdiccional debido a la naturaleza mixta de la institución. José Antonio Escudero sintetiza el problema a partir de las bulas papales para la creación del Santo Oficio y el nombramiento del Inquisidor General, propuesto por el Rey y designado por el Papa. A causa de este cruce, la institución depende del Pontífice, pero éste no puede precisar «las competencias de quienes en realidad eran presidente y consejeros de un organismo de la administración central de la monarquía»; en una situación similar se encuentra el rey, pues aunque en la práctica mediatizó la gestión de la Suprema, «tampoco estaba en condiciones de fijar por escrito, según fue usual en las instrucciones a otros Consejos, las facultades, derechos y deberes de quienes ejercían una jurisdicción que teóricamente le era ajena» (2005: 219) ${ }^{25}$. En la empresa 27, Saavedra afronta

25. Como demuestra Puyol Buil, esta ambigüedad jurisdiccional se zanjó a favor del Estado o de Roma según el peso político que estos poderes tuvieron a lo largo del siglo Xvir. Durante la primera parte del reinado de Felipe IV la corona mantuvo bajo su dominio al Santo Oficio, pero tras la caída de Olivares y el tratado de Westfalia los términos se invirtieron y en 1650 el Papa llegó incluso a amenazar con disolver la Inquisición. El pensamiento político sigue un camino inverso: se parte de una perspectiva según la cual la monarquía está subordinada a Roma (Barbosa y Ribadeneyra) y luego se afianza la idea, ya anunciada por Álamos, de que el Papa debe concentrarse exclusivamente en el ámbito espiritual. 
el problema sin establecer una solución definitiva. Por una parte, afirma que la herejía está «fuera de la jurisdicción del príncipe»; poco después sostiene que es un problema del Estado, porque como puede amenazar el orden establecido, al soberano le "conviene obligar a los súbditos a que, como los alemanes antiguos, tengan por mayor santidad y reverencia creer que saber las cosas de Dios» (283). En la empresa 24 destaca que la unidad religiosa es un asunto del príncipe, porque la discordia en esta materia tendría graves consecuencias para el reino. Pero enseguida subraya que «arbitrar en el culto y accidentes de la religión [...] pertenece derechamente a la cabeza espiritual, por la potestad que a ella sola concedió Cristo» (265-266). Con estas observaciones, Saavedra busca un equilibrio en las jurisdicciones y mantiene el estado contradictorio en el que se encuentran. En sintonía con esto, en la empresa 94 agrega que el príncipe debe acatar los privilegios y derechos del Papa, defendiendo «con reputación y valor los propios cuando no se oponen a aquéllos, sin admitir novedades, perjudiciales a los reinos, que no resultan en beneficio espiritual de los vasallos» $(866)^{26}$.

Aunque Gracián no aborda de manera directa estos problemas, su idea secular de la virtud tiene consecuencias para la cuestión jurisdiccional ${ }^{27}$. En efecto, esa visión lo lleva al borde de una solución distinta en este sentido. En las palabras finales de El Político afirma que el mayor logro de Fernando el Católico fue elegir como sucesora a la casa de Austria:

Casa que después que ella reina no sabe la Iglesia del Señor qué son cismas, ni los conoce. Casa que volvió los Sumos Pontífices de Aviñón a su trono de Roma, y mantiene su autoridad suprema. Casa que la levantó Dios para muralla de la cristiandad contra la potencia otomana. Casa que la fortaleció Dios para ser martillo de los herejes de Bohemia, Hungría, Alemania, Flandes y aun en Francia. Casa que la formó Dios para riquísimo número de santos, emperadores, emperatrices, reyes, reinas y archiduques. Casa que la extendió Dios para toda la redondez de la tierra, para dilatar por toda ella su Santa Fe y Evangelio (92-93).

Para Gracián, la autoridad del solio pontificio depende de la acción política de los Austrias y esto sugiere que la Iglesia pierde su poder secular. Como dice Tulio Halperín Donghi en términos generales, «la fe cristiana aparece como uno de los cimientos de una ciudad terrena, fuertemente implantada en el mundo, que es sin embargo menos la rival que la condición necesaria de la ciudad de Dios» (1985: 41). ¿Era conciente Gracián de los alcances que tenía el final de $E l$ Político? Difícil decirlo, pero ese final es coherente con la forma mediante la cual comprende los vínculos entre política y religión. Si el hombre se gana el cielo por su comportamiento moral, el príncipe lo logra por definir acciones políticas

26. Por cierto, la máxima es algo general, pero se esclarece cuando al final pone como ejemplo a Fernando el Católico, quien «Respetó la jurisdicción eclesiástica y conservó la real» (932).

27. Como demuestra Alberto Montaner Frutos, Gracián no se ocupó de la naturaleza del poder. 
que se encuadran en la ética y que armonizan con el norte de la religión. En los dos casos, el Papa preside un poder espiritual y esto significa que no tiene capacidad para intervenir en asuntos seculares.

Aunque Lancina alcanza un grado de secularización inédito, llega al tipo de soluciones que antes habían planteado Álamos, Pérez y Saavedra. Por un lado, mantiene la subordinación espiritual del príncipe al Papa y recuerda que los preceptos y las leyes emanadas de los concilios deben tener fuerza de ley. Por el otro pone al descubierto los aspectos materiales del problema jurisdiccional. Para el autor, el Pontífice no sólo preside un poder espiritual, sino que además posee un Estado, de modo que se debe mantener con él el trato habitual con otros soberanos. Aunque a lo largo del siglo Xvir se tuvo conciencia de esta doble condición, Lancina lo pone de manifiesto de manera directa al afirmar que la cuestión jurisdiccional pasa por un territorio exclusivamente secular. Su recomendación, en consecuencia, es lograr un equilibrio en este sentido.

Si tomamos en cuenta estas observaciones, podemos concluir que el pensamiento político español es una reflexión sobre el sistema de poder que pusieron en práctica los Austrias. Se trata de un sistema político que los tratadistas evidentemente consideraban probado y que no estaban dispuestos a cambiar. El intento de solucionar la crisis abierta por Maquiavelo puede comprenderse, en este sentido, como una búsqueda por asimilar en mayor o menor medida el descubrimiento del florentino a fin de sostener la monarquía española. En ese sistema, la religión no es un mero factor de poder ni tampoco es un engaño para mantener sujeta a la población, sino que funciona como el sustento mismo del poder en tanto es lo que lo convierte en algo verdadero. Para los tratadistas, la monarquía de los Habsburgo es poderosa porque opera en un campo que está incluido en el plan general de Dios. Al respecto, creo que es importante confrontar estas reflexiones con las agudas conclusiones a las que llega Puyol Buil en Inquisición y política en el reinado de Felipe IV. Según sostiene el historiador, el proceso a Jerónimo de Villanueva puede comprenderse como un entramado entre poder y verdad. El acusado tiene razón mientras mantiene su poder. Gracias al apoyo de Olivares, logra la suspensión del proceso y se sobrepone a la Inquisición. Pero cuando pierde el poder, el nuevo inquisidor general, Diego de Arce y Reynoso, reactiva el proceso y de esa forma cambia el lugar de la verdad. Momento fugaz, sin embargo, porque el poder que ostenta Arce es un poder delegado, de modo que finalmente es el Pontífice quien decide la suerte de Villanueva, acallando su voz y sobreponiéndose incluso al propio rey. La verdad, como demuestra Puyol Buil, es una cuestión de poder. Los tratadistas políticos revelan que lo inverso también es cierto: el poder únicamente es duradero si se lo ejerce en nombre de una fuente de legitimidad y por consiguiente si se mantiene bajo el amparo de una verdad como la que proporciona la religión.

La modernidad del pensamiento político español se encuentra en lo que desde otro punto de vista entenderíamos como su antigüedad. Demuestra que la religión, como luego la nación, son claves para el ejercicio de la política, pues la 
acción realista únicamente tiene posibilidad si alcanza a justificarse a partir de esas fuentes de legitimidad. Por supuesto, como dice Lefort a partir de Maquiavelo, la religión, como la nación, son imposiciones ideológicas y de manera drástica son pantallas que mantienen regulado el conflicto social. Si seguimos el ejemplo de la razón de Estado, podemos decir que constituyen herencias de una situación de dominio pasada, como es el caso de la monarquía católica tras el proceso de confesionalización de Felipe II. Pero el pensamiento político español pone en evidencia que la verdadera disputa se encuentra en definir los alcances de la fuente de legitimidad para de esa forma operar en el mundo de una manera aceptable para los gobernados. Con todos los aspectos que nos distancian de ella, la razón de Estado demuestra esta cuestión central del poder gubernamental, que todavía define algunas de las condiciones bajo las cuales éste opera en la actualidad. 


\section{Bibliografía}

Álamos de Barrientos, Baltasar, Tácito español ilustrado con aforismos, Madrid, Luis Sánchez, 1614.

Ankersmit, Frank, «Historia y teoría política», en Giro lingüístico, teoría literaria y teoría histórica, Buenos Aires, Prometeo, 2011, 107-132.

Aranda Pérez, José Francisco y López, David Martín, «Pensamiento político español more societatis Jesu: entre la teología y la razón de Estado", en Los jesuitas. Religión, política y educación, José Martínez Millán, Henar Pizarro Llorente y Esther Jiménez Pablo (coords.), Madrid, Universidad Pontificia de Comillas, 2012, Tomo II, 1309-1338.

Barbosa Homen, Pedro. Discursos de la jurídica y verdadera razón de Estado, Coimbra, Nicolás Carvallo, 1629.

Botero, Giovanni, Razón de Estado, Burgos, Sebastián de Cañas, 1603.

Burke, Peter, "Tacitism, scepticism and reason of state», en The Cambridge History of Political Thought 1450-1700, James Henderson Burns (coord.), Cambridge, Cambridge University Press, 1994, 479-499.

Cantarino, Elena. "El concepto de razón de Estado en los tratadistas de los siglos Xvi y XviI (Botero, Rivadeneira y Settala)», Res Publica, 2, 1 (1998), 7-24.

-, «Gracián y el Oráculo manual: de los medios del arte de la prudencia y de la ocasión", Eikasia. Revista de Filosofía 37 (2011), 151-167. http://www. revistadefilosofia.com (última consulta: 1/1/2014).

Cid VÁzquez, María Teresa, Tacitismo y razón de Estado en los "Comentarios politicos» de Juan Alfonso de Lancina, tesis doctoral, Facultad de Derecho, Universidad Complutense de Madrid, 2001. http://biblioteca.ucm.es/tesis/ der/ucm-t25213.pdf (última consulta: 1/1/2014).

Donaldson, Peter, Machiavelli and Mystery of State, Cambridge, Cambridge University Press, 1992.

Egido, Aurora, «El arte de la memoria y el Criticón», Gracián y su época, Zaragosa, Institución Fernando el Católico, 1986, 22-66.

—, «Introducción», en El Discreto, Baltasar Gracián, Alianza, Madrid, 1997.

Elliot, John y de la Peña, José, Memoriales y cartas del Conde-Duque de Olivares, Tomo I, Madrid, Alfaguara, 1978.

Escudero, José Antonio, Estudios sobre la Inquisición, Marcial Pons, 2005.

Fernández Álvarez, Manuel, Corpus Documental de Carlos V. Tomo II, Salamanca, Consejo Superior de Investigaciones Científicas, 1975.

Fernández-Santamaría, José Antonio, Razón de Estado y política en el pensamiento español del Barroco (1595-1640), Madrid, CEC, 1986.

Foucault, Michel, Seguridad, territorio, población, Buenos Aires, Fondo de Cultura Económica, 2006.

García Gibert, Javier, «Medios humanos y medios divinos en Baltasar Gracián (la dialéctica ficcional del aforismo 251)», Criticón 73 (1998), 61-82. 
Gotor, Miguel, «Hagiografía y censura de libros: el quinto capítulo sobre los milagros de la Vida de Ignacio de Loyola de Pedro de Ribadeneyra entre corte de reyes y obediencia romana", en Los jesuitas, Tomo II, 1007-1028.

Gracián, Baltasar, Obras completas, Tres tomos, Buenos Aires, Poblet, 1943.

Guicciardini, Francesco, Opere inedite, Firenze, Barbera, Bienchi e comp., 1857.

García López, Jorge, «Quevedo y Saavedra: dos contornos del seiscientos», $L a$ Perinola. Revista de Investigación Quevediana, 2, 1998, 237-262.

—, «El estilo de una corte: apuntes sobre Virgilio Malvezzi y el laconismo hispano", Quaderns d'Italia, 6, 2001, 155-169.

Halperín Donghi, Tulio, Tradición política española e ideología revolucionaria de Mayo, Buenos Aires, Centro Editor de América Latina, 1985.

Lancina, Juan Alfonso, Comentarios políticos a los Anales de Cayo Vero Cornelio Tacito, Madrid, Oficina de Melchor Álvarez, 1687.

LEFort, Claude, «Maquiavelo y la veritá effetuale», en El arte de escribir y lo politico, Barcelona, Hereder, 2007, 233-277.

Machiavelli, Niccolò, Il Principe, Turin, Einaudi, 1995.

Marañón, Gregorio, «El Conocimiento de las Naciones y el Norte de Príncipes ¿son obras de Antonio Pérez o de Baltasar Álamos Barrientos?», en Estudios Dedicados a Menéndez Pidal, Tomo I, Madrid, Consejo Superior de Investigaciones Científicas, 1950, 317-347.

—, Antonio Pérez, Madrid, Espasa-Calpe, 1947.

Maravall, José Antonio. Estudios de historia del pensamiento español, Madrid, Cultura Hispánica, 1975.

Martínez Millán, José, «El confesionalismo de Felipe II y la Inquisición», Trocadero 6-7 (1995), 103-124.

—, «El nacimiento de la Compañía de Jesús: proyecto religioso y problemas políticos», en Los jesuitas, Tomo I, 21-42.

Montaner Frutos, Alberto, «El político don Fernando el Católico», en Baltasar Gracián: estado de la cuestión y nuevas perspectivas, Aurora Egido y María Carmen Marín Pina (coords.), Zaragoza, Institución Fernando el Católico, 2001, 47-58.

NaudÉ, Gabriel, Consideraciones politicas sobre los golpes de Estado, Madrid, Tecnos, 1998.

Navarro Lozano, Julián, La Compañia de Jesús y el poder en la España de los Austrias, Madrid, Cátedra, 2005.

Pérez, Antonio, Norte de principes, Madrid, Imprenta de Don Pedro Marin, 1788.

Pérez Lasheras, Antonio, "Gracián y la recepción del canon poético", en $E l$ canon poético del siglo XVII, Begońa López Bueno (dir.), Sevilla, Universidad de Sevilla/Grupo PASO, 2010, 453-474.

Prades Vilar, Mario, "La teoría de la simulación de Pedro de Ribadeneyra y el "maquiavelismo de los antimaquiavélicos"”, Ingenium 5 (2011), 133-165. 
Puyol Buil, Carlos, Inquisición y política en el reinado de Felipe IV, Madrid, Consejo Superior de Investigaciones Científicas, 1993.

Ribadeneyra, Pedro, Tratado del Principe Cristiano, Madrid, Imprenta P. Madrigal, 1595.

Rivera García, Antonio, «La religión de la conquista del mundo: aproximación al imperium mundi jesuítico», Eikasia. Revista de Filosofía, 37 (2011), 59-81.

Rubinstein, Nicolai, «Italian political thought, 1450-1530», en The Cambridge History of Political Thought 1450-1700, James Henderson Burns (coord.), Cambridge, Cambridge University Press, 1994, 30-65.

SaAvedra Fajardo, Diego, Empresas politicas. Edición de Quintín Aldea Vaquero. Madrid, Biblioteca de la literatura y el pensamiento hispánicos, 1976.

SAUQuillo, Julián, «Baltasar Álamos Barrientos en la (pre)modernidad tacitista", Res publica, 19 (2008), 235-260.

Senellart, Michel, Machiavélisme et raison d'État, PUF, Paris, 1989.

Toffanin, Giuseppe, Machiavelli e il Tacitismo, Padova, Draghi, 1921.

Villanueva López, Jesús, «La influencia de Maquiavelo en las Empresas políticas de Diego Saavedra Fajardo", Studia historica 19 (1998), 169-196.

Viroli, Maurizio, De la política a la razón de Estado, Madrid, Akal, 2009. 